\title{
FAKTOR-FAKTOR YANG MEMPENGARUHI TAX $A$ VOIDANCE DENGAN KEPEMILIKAN INSTITUSIONAL SEBAGAI VARIABEL PEMODERASI
}

\author{
Vivi Adeyani Tandean \\ Piter Nainggolan \\ Institut Bisnis dan Informatika Kwik Kian Gie \\ Universitas Bunda Mulia \\ vivi.tandean@gmail.com
}

\begin{abstract}
Taxation is an important issue to sustain a country's revenue. The main obstacle in the context of state income tax in this sector is tax avoidance. Minimizing of tax burden can be influenced by executive's character, company's size, profitability and institutional ownership.This study aims to examine the factors that affect tax avoidance. This study uses 120 manufacturing companies. Sample methods in this study is judgment sampling. This study's hypothesis is tested with classical assumptions and multiple regression analysis and residual regression analysis using SPSS version 20 software. Conclusions for this research is executive's character does not have sufficient evidence to have impact on tax avoidance. Company's size and profitability have sufficient impact on tax avoidance. Institutional ownership variable can be able to moderate various factor which have impact on tax avoidance.
\end{abstract}

Keywords : tax avoidance

\section{Pendahuluan}

Bagi negara maju, pajak merupakan unsur penting dalam menopang penerimaan Negara. Pemerintah menggunakan pajak sebagai sumber pembiayaan Negara yang paling penting dalam APBN. Target penerimaan pajak setiap tahun diharapkan terus meningkat. Selain itu pajak ditempatkan sebagai salah satu bentuk kontribusi masyarakat untuk ikut berpartisipasi dalam rangka membantu pelaksanaan tugas bernegara yang ditangani oleh pemerintah.

Pemerintah sangat mengharapkan adanya sikap taat pajak dari seluruh masyarakat atau badan yang 
merupakan wajib pajak. Sikap taat pajak dalam arti wajib pajak selalu membayar pajak sesuai dengan kondisi sebenarnya merupakan perilaku positif yang akan meningkatkan penerimaan Negara. Hal ini berbeda dengan perusahaan yang memiliki tujuan dalam memaksimalkan laba agar nilai saham perusahaan dapat meningkat dan perusahaan semakin diminati oleh investor. Perbedaan kepentingan ini yang menyebabkan perusahaan berusaha untuk membayar pajak seminimal mungkin dengan melakukan manajemen pajak tanpa melanggar undang - undang. Penghindaran pajak (tax avoidance) merupakan salah satu bentuk manajemen pajak yang dilakukan oleh perusahaan. Di satu sisi penghindaran pajak diperbolehkan secara hukum selama sesuai dengan ketentuan undang - undang yang ada (lawful) tetapi di sisi lain tindakan penghindaran pajak juga tidak diinginkan karena dianggap dapat merugikan penerimaan negara (Ayu 2009:2). Beberapa faktor yang mempengaruhi penghindaran pajak antara lain karakter eksekutif, ukuran perusahaan, profitabilitas, kompensasi eksekutif, struktur hutang, kualitas audit, good corporate governance, kepemilikan ins-titusional dan kepemilikan manajerial.

Rumusan masalah yang akan dibahas dalam penelitian ini adalah apakah karakter eksekutif, ukuran perusahaan dan profitabilitas berpengaruh terhadap tax avoidance dengan kepemilikan institusional sebagai variabel moderating?

\section{Tinjauan Pustaka}

\subsection{Landasan Teori}

\subsubsection{Agency Theory}

Jensen \& Meckling (1976) dalam Anggraini (2006:7) mengatakan bahwa hubungan keagenan merupakan suatu kontrak antara satu atau lebih orang (principas) yang menghendaki orang lain (manajer) untuk melaksanakan jasa dengan cara mendelegasikan wewenang pengambilan keputusan kepada agen. Di dalam hubungan keagenan, terdapat 3 faktor yang mempengaruhi yaitu biaya pengawasan (monitoring costs), biaya kontrak (contracting costs), dan visibilitas politis. Manajemen sebagai pengelola perusahaan lebih banyak mengetahui informasi internal sehingga terdapat kesenjangan atau gap akan luasnya informasi yang dimiliki oleh 
manajemen dengan pemilik. Manajemen sebagai agen, secara moral bertanggung jawab untuk mengoptimalkan keuntungan para pemilik (prinsipal), fokus pada pemenuhan kepentingan pribadi, yaitu memaksimalkan pemenuhan kebutuhan ekonomi dan psikologisnya. Sementara pemegang saham akan fokus pada peningkatan nilai sahamnya. Dengan demikian terdapat dua kepentingan yang berbeda di dalam perusahaan dimana masing masing pihak berusaha untuk mencapai atau mempertahankan tingkat kemakmuran yang dikehendaki. Adanya benturan kepentingan antara keduanya inilah yang memicu munculnya agency theory (Rusydi dan Martani,2014). Dalam rangka manajemen bertindak selaras dengan tujuan pemilik, prinsipal harus memberi insentif yang sesuai agar agen termotivasi untuk memenuhi kepentingan prinsipal dan harus dilakukan pengawasan untuk mencegah hal - hal yang tidak diinginkan yang dilakukan oleh agen (Jensen dan Meckling, 1976). Hal tresebut menyebabkan munculnya agency cost, sehingga dapat disimpulkan bahwa agency cost timbul dari agency theory. Meminimalkan agency cost merupakan tantangan yang harus diselesaikan oleh para dewan direksi dan pemegang saham yang harus memikirkan cara dan pemberian insentif yang tepat untuk menjadikan agency cost seminim mungkin (Jensen dan Meckling dalam Hanlon dan Heitzman,2010). Konflik keagenan dapat mempengaruhi tingkat perlakuan pajak agresif. Permasalahan keagenan dimana terdapat perbedaan kepentingan bagi agen dan prinsipal memicu timbulnya perilaku aggressive tax avoidance. Hal ini dikarenakan di satu sisi manajemen menginginkan peningkatan kompensasi melalui laba yang tinggi sedangkan sisi lainnya pemegang saham ingin menekan biayapajak melalui laba yang rendah. Maka dalam rangka menjembatani agency problem ini timbul perilaku aggressive tax avoidance dalam rangka mengoptimalkan kedua kepentinga tersebut.

\subsubsection{Karakter Eksekutif}

Pemimpin adalah ahli strategi yang menetapkan tujuan organisasi; sedang manajer memusatkan perhatian pada cara-cara agar organisasi dapat mencapai tujuan tersebut (Dale Timpe, 1993: ix). Menurut Low dalam Budiman (2012:3) dalam menjalankan tugasnya sebagai pemimpin perusahaan, eksekutif memiliki dua karakter yakni risk taker dan risk averse. Risk taker adalah eksekutif 
yang lebih berani dalam mengambil keputusan bisnis dan biasanya memiliki dorongan yang kuat untuk memiliki penghasilan, posisi, kesejahteraan dan kewewenangan yang lebih tinggi (Maccrimon dan Wehrung dalam Budiman, 2012: 3). Dibandingkan dengan risk taker, eksekutif risk averse lebih menitik beratkan pada keputusan-keputusan yan tidak mengakibatkan resiko yang lebih besar. Karakter eksekutif dapat diukur dengan dengan resiko perusahan dengan melihat resiko keputusan pimpinan perusahaan melalui standar deviasi perusahaan. Semakin tinggi nilai standar deviasi masing - masing perusahaan maka semakin pemimpin perusahaan tersebut adalah risk taker. Maccrion dan Wehrung (dalam Budiman, 2012) menyebutkan eksekutif yang memiliki karakter risk taker adalah eksekutif yang lebih berani dalam mengambil keputusan.

\subsubsection{Ukuran Perusahaan}

Menurut Reviani (2012) ukuran perusahaan adalah nilai yang memberikan gambaran besar atau kecilnya sebuah perusahaan. Beberapa proksi yang biasa digunakan untuk mewakili ukuran perusahaan adalah jumlah karyawan, total aset, jumlah penjualan, dan kapitalisasi pasar. Semakin banyak jumlah karyawan berarti semakin banyak hasil yang diproduksi. Semakin besar aset berarti semakin banyak modal yang ditanam, semakin tinggi jumlah penjualan berarti semakin banyak perputaran uang, dan semakin tinggi kapitalisasi pasar maka perusahaan semakin dikenal dalam masyarakat.

Reviani (2012) menjelaskan bahwa perusahaan yang memiliki aset lebih besar biasanya memiliki peran yang lebih besar sebagai pemegang kepentingan. Hal tersebut akan membuat kebijakan yang dikeluarkan oleh perusahaan besar akan memberikan dampak yang lebih besar terhadap kepentingan publik dibanding dengan perusahaan kecil. Oleh karena itu, perusahaan besar akan menjadi pusat perhatian oleh masyarakat sehingga mereka akan lebih berhati-hati dalam melakukan pelaporan keuangan. Sehingga kondisi laporan keuangan yang dilaporkan harus lebih kuat. Semakin besar ukuran perusahaan akan semakin mempengaruhi perusahaan untuk melakukan aktivitas 
penghindaran pajak untuk mancapai optimal tax saving.

\subsubsection{Profitabilitas}

Profitabilitas atau kemampuan memperoleh laba merupakan sebuah ukuran dalam persentase yang digunakan untuk menilai sejauh mana perusahaan mampu menghasilkan laba pada tingkat yang dapat diterima. Angka profitabilitas dinyatakan antara lain dalam angka laba sebelum atau sesudah pajak, laba investasi, pendapatan per saham dan laba penjualan. Nilai profitabilitas menjadi norma ukuran bagi perusahaan. Penelitian ini mengukur profitabilitas perusahaan dengan menggunakan proksi ROA (return on assets). Return on assets merupakan sebuah rasio antara laba bersih yang berbanding terbalik dengan keseluruhan aktiva untuk menghasilkan laba. Rasio ini menunjukkan seberapa besar laba bersih yang diperoleh perusahaan diukur dari nilai aktivanya. Menurut Horne dan Wachowicz (2005:235) menghitung return on assets dengan menggunakan rumus laba bersih setelah pajak dibagi dengan total aktiva. Menurut Widyaningsih (2012), Return on assets mampu merefleksikan keuntungan bisnis dan mewakili efektifitas perusahaan yang mencerminkan kinerja manajemen dalam pemanfaatan total 174 sset untuk menghasilkan laba yang diinginkan oleh perusahaan. Dengan kata lain, return on assets mampu mengukur kemampuan perusahaan menghasilkan keuntungan pada masa lampau untuk kemudian diproyeksikan di masa yang akan datang. Semakin besar profitabilitas yang dihasilkan perusahaan maka semakin besar jumlah pajak yang harus dibayarkan.Tindakan untuk menurunkan laba kena pajak ini merupakan situasi ketika perusahaan melakukan kebijakan pajak tertentu dan suatu hari terdapat kemungkinan tindakan pajak tersebut tidak akan diaudit atau dipermasalahkan dari sisi hukum, namun tindakan ini berisiko karena ketidakjelasan posisi akhir, apakah tindakan pajak tersebut dianggap melanggar atau tidak melanggar hukum yang berlaku (Hite dan McGill dalam Sari dan Martani, 2010). Pemilik perusahaan akan cenderung lebih menyukai apabila perusahaan melakukan tindakan pajak agresif dalam tax avoidance karena pajak merupakan biaya bagi 
perusahaan dan pemilik perusahaan (Chen et al, 2008).

\subsubsection{Kepemilikan Institusional}

Kepemilikan institusional adalah proporsi kepemilikan saham yang dimiliki oleh pemilik institusi dan blockholders pada akhir tahun (Wahyudi dan Pawestri dalam Simarmata dan Cahyonowati, 2014). Saham institusional adalah proporsi kepemilikan saham yang dimiliki oleh lembaga, seperti asuransi, bank atau institusi lain (Simarmata dan Cahyonowati, 2014). Kepemilikan institusional ini memiliki pengaruh yang penting bagi perusahaan dalam memonitor manajemen, karena akan mendorong peningkatan pengawasan yang lebih optimal sehingga mempengaruhi tindakan tax avoidance. Semakin besar kepemilikan institusional yang dimiliki oleh perusahaan maka semakin kecil tindakan kebijakan pajak agresif karena pemilik institusional sangat memperhatikan dampak jangka panjang yang akan dihasilkan terhadap tindakan pajak agresif (Zemzem dan Ftouhi, 2013). Maka dari itu, semakin besar rasio kepemilkan institusional akan menghasilkan pengendalianyang semakin besar, sehingga indikasi terjadinya konflik agensi semakin kecil dan semakin kecil pula kemungkinan dilakukannya tax avoidance.

\subsubsection{Tax Avoidance}

Kewajiban dalam membayar pajak yang diharuskan bagi perusahaan telah mempengaruhi banyak faktor dalam pengambilan keputusan. Hal ini menyebabkan banyaknya keputusan manajerial yang dirancang khusus untuk meminimalkan besarnya pajak yang harus dibayar oleh perusahaan (Sartori, 2008:12). Meminimalisasi beban pajak dapat dilakukan dengan berbagai cara, mulai dari yang masih berada dalam bingkai peraturan perpajakan sampai dengan yang melanggar peraturan perpajakan. Upaya meminimalkan pajak secara eufimisme sering disebut dengan perencanaan pajak (taxplanning). Umumnya perencanaan pajak merujuk pada proses merekayasa usaha dan transaksi wajib pajak agar hutang pajak berada dalam jumlah minimal tetapi masih dalam bingkai peraturan perpajakan (Suandy, 2008: 7). Istilah yang sering digunakan untuk 
penghindaran pajak yang masih memenuhi ketentuan perpajakan adalah tax avoidance, sedangkanistilah tax evasion digunakan untuk penghindaran pajak dengan cara melanggar peraturan perpajakan. Tax avoidance dapat diartikan sebagai cara yang tidak sah (namun tidak perlu melanggar hukum) dalam mengurangi hutang pajak yang tidak melanggar ketentuan undang-undang tetapi dengan jelas melanggar jiwa undangundang dengan memanfaatkan celah yang ada (loopholes) (Sartori, 2008: 11). Balter dalam Zain (2005: 49) mendefinisikan penghindaran pajak sebagai usaha yang dilakukan oleh wajib pajak apakah berhasil atau tidak untuk mengurangi atau sama sekali menghapus utang pajak yang tidak melanggar ketentuan peraturan perundang-undangan perpajakan. Sedangkan Anderson dalam Zain (2005: 50) menyatakan bahwa penghindaran pajak adalah cara mengurangi pajak yang masih dalam batas ketentuan peraturan perundangundangan perpajakan dan dapat dibenarkan, terutama melalui perencanaan pajak.
Tax avoidance dibedakan menjadi penghindaran pajak yang diperbolehkan (acceptable tax avoidance) dan yang tidak diperbolehkan (unacceptable tax avoidance) (Fadhilah, 2014). Perbedaan antara kedua jenis tax avoidance ini seperti yang diungkapkan oleh Slamet dalam Rusydi dan Martani (2014) adalah ada atau tidaknya tujuan usaha yang baik, apakah tindakan yang dilakukan semata-mata untuk menghindari pajak, apakah tindakan sesuai dengan jiwa undang-undang dan maksud dari pemerintah, serta apakah melakukan transaksi yang direkayasa.Sartori (2008: menegaskan bahwa konsep dari tax avoidance merupakan sebuah konsep terhadap perlindungan pajak. Pengertian secara luas mengenai konsep ini adalah sebuah transaksi atau perjanjian yang dirancang untuk mengurangi atau menunda perpajakan dengan cara-cara tertentu. Dalam melakukan tax avoidance perusahaan akan mendapatkan keuntungan dalam penghematan pajak. Semakin besar jumlah pajak yang dapat dihindari, maka semakin 
besar pula penghematan pajak yang dapat dilakukan oleh perusahaan.

\subsection{Hipotesis}

Berdasarkan hal tersebut, hipotesis penelitian ini adalah :

$\mathbf{H a}_{1}$ :Karakter eksekutif berpengaruh terhadap tax avoidance dengan kepemilikan institusional sebagai variabel moderasi.

Ha2:Ukuran perusahaan berpengaruh terhadap tax avoidance dengan kepemilikan institutional sebagai variabel moderasi.

$\mathrm{Ha}_{3}$ :Profitabilitas berpengaruh terhadap tax avoidance dengan kepemilikan institusional sebagai variabel moderasi.

\section{Metode Penelitian}

\subsection{Penyajian Data}

Obyek dalam penelitian ini adalahperusahaan manufaktur Go Public di Indonesia yang telah terdaftar di Bursa Efek Indonesia periode 2010-2013 berdasarkan Indonesian Capital Market Directory (ICMD). Perusahaan-peusahaan tersebut harus telah mengeluarkan auditedannual report secara lengkap, tidak delisting, menggunakan mata uang rupiah, memiliki laba sebelum pajak dan setelah pajak bernilai positif serta currentETR (effective tax rate) diatas 0 .

\subsection{Definisi Operasional Variabel} dan Pengukuran Variabel Penelitian

1. Variabel Dependen

Tax Avoidance menggunakan proksi current ETR (effective tax rate) unutk mengukur seberapa besar perusahaan melakukan penghindaran pajak. Hanlon dan Heitzman (2010) menghitung current ETR dengan membagi currenttax expense dengan pre-tax income.

2. Variabel Independen

a. Karakter Eksekutif

Untuk mengetahui karakter eksekutif maka digunakan risiko perusahaan (corporate risk) yang dimiliki oleh perusahaan (Paligrova dalam Budiman, 2012: 8). Untuk mengukur risiko perusahaan ini dapat dihitung melalui deviasi standar EBITDA dibagi total asset perusahaan. Rumus deviasi standar dirumuskan sebagai berikut:

$$
R I S K=\sqrt{\sum_{T-1}^{T}\left(E-\frac{1}{T} \sum_{T-1}^{T} E\right)^{2}} /(\mathrm{T}-1)
$$

Keterangan: 
$\mathrm{E}=$ EBITDA (earning before interest, tax and depreciation assets)

/ Total Asset

$\mathrm{T}=$ Total Sampel

Perusahaan yang memiliki nilai standar deviasi melebihi nilai ratarata nilai standar deviasi seluruh perusahaan akan diberi nilai 1 yang mewakili pemimpin yang risk taker dan perusahaan yang memiliki nilai standar deviasi kurang dari nilai ratarata standar deviasi seluruh perusahaan akan diberi nilai 0 yang mewakili pemimpin yang risk averse (Harto dan Hanafi, 2014:4).

b. Ukuran Perusahaan

Ukuran perusahaan dihitung menggunakan natural logarithm total asset yang dimiliki oleh perusahaan.

c. Profitabilitas

Dalam penelitian ini, profitabilitas diukur dengan rasio return on asset (ROA) yang didapatkan dari earning after tax (EAT) dibagi dengan total assets.

3. Variabel Moderasi

Kepemilikan institusional adalah proporsi kepemilikan saham yang dimiliki oleh pemilik institusi dan blockholders dibagi dengan jumlah saham perusahaan yang beredar pada akhir tahun. Kepemilkan institusional ini dinyatakan dalam persentase.

\subsection{Teknik Analisis Data}

1. Analisis Deskriptif

Statistik deskriptif digunakan untuk mendeskripsikan data yang ada pada penelitian ini yang terdiri dari karakter eksekutif, ukuran perusahaan, profitabilitas dan tax avoidance.. Pengukuran yang digunakan dalam penelitian ini yaitu nilai minimum, nilai maximum, mean dan standar deviasi.

2. Uji Asumsi Klasik

Uji asumsi klasik dilakukan dalam penelitian ini untuk menguji apakah data memenuhi asumsi klasik. Uji asumsi klasik terdiri dari uji normalitas, uji autokorelasi, uji multikolonieritas dan uji heterokedastisitas. Uji normalitas menggunakan uji nonparametrik Kolmogrov-Smirnov, uji autokorelasi menggunakan uji

Durbin-Watson, uji multikolonieritas dengan melihat nilai tolerance dan variance 


$\begin{aligned} & \text { inflation factor (VIF) sedangkan } \\ & \text { uji } \\ & \text { heterokedastisitas } \\ & \text { menggunakan uji Glejser. Uji } \\ & \text { asumsi klasik dalam penelitian ini } \\ & \text { semuanya telah memenuhi } \\ & \text { persayaratan dan model layak } \\ & \text { digunakan. }\end{aligned}$

Analisis Regresi Berganda

Analisis regresi berganda (multiple regression analysis) digunakan untuk menguji pengaruh dua atau lebih variabel bebas terhadap variabel terikat. Sebagai alat deskriptif, regresi berganda digunakan sebagai alat untuk menarik kesimpulan untuk menguji hipotesis dan mengestimasi nilai-nilai populasi (Cooper dan Schindler, 2006: 307).Analisis regresi berganda juga mengukur kekuatan hubungan antara dua variabel atau lebih, serta menunjukkan arah hubungan antara variabel dependen dengan variabel independen pada persamaan pertama.Tujuan dari teknik regresi adalah menaksir besarnya parameter $\mathrm{b}_{0,1,2,3,4,5,6,7}$ dari model di atas. Pada persamaan kedua, digunakan analisis regresi variabel moderasi dengan metode residual. Pada metode residul dilakukan dengan mere-gresikan variabel dependen terhadap nilai mutlak residual dari regresi variabel bebas terhadap variabel yang dihipotesiskan sebagai variabel moderasi. Adapun persamaan untuk menguji hipotesis secara keseluruhan pada penelitian ini adalah sebagai berikut:

$$
\begin{aligned}
& Y=b_{0}+b_{1 X 1}+b_{2} X_{2}+b_{3} X_{3}+\varepsilon \ldots \ldots(1) \\
& Y=b_{0}+b_{1 X 1}+b_{2} X_{2}+b_{3} X_{3}+b_{4} X_{4}+b_{5} \\
& X_{1} \quad X_{4}+b_{6} X_{2} X_{4}+b_{7} X_{3} X_{4} \\
& \varepsilon \ldots \ldots \ldots \ldots \ldots(2)
\end{aligned}
$$

Keterangan:

Y: Current ETR

$\mathrm{b}_{0}$ : konstanta

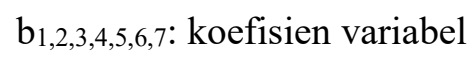

$\mathrm{X}_{1}$ : karakter eksekutif (KE)

$\mathrm{X}_{2}$ : ukuran perusahaan (UP)

$\mathrm{X}_{3}$

: return on

$\operatorname{assets(\mathrm {ROA})}$

$\mathrm{X}_{4}$ : kepemilikan institusional

$\varepsilon$

:residual of error

1. Pengujian Hipotesis

Ketepatan fungsi regresi sampel dalam menaksir nilai aktual dapat diukur dari model Goodness of Fit fungsi regresi tersebut. Secara statistik pengujian hipotesis ini dapat diukur dari nilai koefisien determinasi $\left(\mathrm{R}^{2}\right)$, nilai statistik $\mathrm{F}$, dan nilai statistik t. Perhitungan statistik signifikan apabila nilai uji statistik berada dalam daerah kritis, yaitu 
daerah dimana $\mathrm{H}_{0}$ ditolak. Dan menjadi tidak signifikan bila nilai uji statistik berada dalam daerah $\mathrm{H}_{0}$ diterima.

4.Hasil Penelitian dan

Pembahasan

\subsection{Analisis Deskriptif}

Uji analisis deskriptif dilakukan terhadap data karakter eksekutif, ukuran perusahaan, profitabilitas, kepemilikan institusional dan tax avoidance. Berikut ini disajikan hasil uji statistis deskriptif.

Tabel 1

Hasil Analisis Deskriptif

\begin{tabular}{|c|c|c|c|c|c|c|}
\hline \multicolumn{7}{|c|}{ Descriptive Statistics } \\
\hline & & $\mathrm{N}$ & Minimum & Maximum & Mean & Std. Deviation \\
\hline KE_X1 & & 120 & 0 & 1 & ,31 & ,464 \\
\hline UP_X2 & & 120 & 25,22112 & 30,36219 & 27,6356094 & 1,21183547 \\
\hline ROA_X3 & & 120 &, 02200 & ,23300 &, 0830275 &, 05497538 \\
\hline INST_X4 & & 120 & ,29704 & ,96210 & ,7104992 &, 17323541 \\
\hline ETR_Y & & 120 & ,00404 & ,45214 & ,2416910 & ,07478271 \\
\hline $\begin{array}{l}\text { Valid } \\
\text { (listwise) }\end{array}$ & $\mathrm{N}$ & 120 & & & & \\
\hline
\end{tabular}

Sumber: Data sekunder yang diolah

Pada tabel 1 menunjukkan bahwa jumlah data yang digunakan dalam penelitian ini ada 120 perusahaan. Variabel dependen current ETR menunjukkan nilai minimum sebesar 0,00404 yang mengindikasikan tingginya kemungkinan terjadinya tax avoidance. Sedangkan nilai maksimumsebesar $\quad 0,45214$ mengindikasikan semakin kecilnya peluang terjadinya tax avoidance. Nilai rata-rata current ETR pada penelitian ini sebesar 0,2416908 yang menunjukkan bahwa potensi terjadinya tax avoidance pada perusahaan cukup tinggi.

Variabel independen dalam analisis deskriptif ini, yaitu karakter 
eksekutif yang diukur dengan resiko perusahaan, memiliki nilai mean sebesar 0,31. Nilai minimum sebesar 0 dan nilai maksimum sebesar 1 serta nilai standar deviasi sebesar 0,464. Hal ini menunjukkan bahwa banyak pemimpin perusahaan yang tidak berani dalam mengambil keputusan untuk melakukan tindakan tax avoidance.

Variabel independen selanjutnya adalah ukuran perusahaan yang memiliki nilai rata-rata total assets sebesar 27,6356094 juta nilai minimum sebesar 25,22112 juta dan nilai maksimum sebesar 30,36219 juta dengan standar deviasi sebesar 1,21183547 .

Variabel independen berikutnya dalah profitabilitas yang diukur dengan return on assets. Nilai rata rata ROA sebesar $0,830275(83 \%)$ dengan nilai minimum sebesar 0,02200 dan nilai maksimum sebesar 0,23300 .

Variabel moderasi adalah kepemilikan institusional memiliki nilai rata - rata sebesar 0,7104992 yang berarti kepemilikan perusahaan oleh pohak institusi rata - rata sebesar $71 \%$ dengan persentase paling sedikit berjumlah 0,29704 atau hanya $29,7 \%$ dari saham perusahaan beredar yang dimiliki oleh institusi. Kepemilikan institusional memiliki nilai tertinggi sebesar 0,96210 atau $96,21 \%$ dari saham beredar.

Pengujian Hipotesis 1: Apakah karakter eksekutif berpengaruh terhadap tax avoidance dengan kepemilikan institusional sebagai variabel moderasi?

Hasil uji statistik t menunjukkan nilai signifikan sebesar $0,137>0,05(5 \%)$. Hasil ini menunjukkan bahwa resiko keputusan pimpinan perusahaan tidak berpengaruh terhadap penghindaran pajak. Adanya kepemilikan institusional sebagai pengawas dalam pengambilan keputusan yang dilakukan pimpinan perusahaan. Semakin banyak keputusan yang diambil perusahaan melalui beberapa pihak dan pengawasan yang luas akan semakin mempengaruhi keputusan yang diambil oleh pimpinan perusahaan tersebut. Pimpinan perusahaan yang risk averse lebih cenderung berhati - hati dalam mengambil keputusan yang beresiko bagi perusahaannya. 
Pengujian Hipotesis 2: Hasil uji statistik t menunjukkan nilai

Apakahukuran perusahaan berpengaruh terhadap tax avoidance dengan kepemilikan institutional sebagai variabel moderasi?

Hasil uji statistik t menunjukkan nilai signifikan sebesar $0,003<0,05$. Hasil ini menunjukkan bahwa ukuran perusahaan berpengaruh negatif terhadap tindakan tax avoidance. Semakin besar ukuran perusahaan akan semakin banyak pihak yang melakukan pengawsan terhadap perusahaan tersebut baik secara internal maupun eksternal. Dengan adanya kepemilikan institusional dalam perusahaan tersebut maka perusahaan akan melakukan manajemen pajak dengan lebih berhati - hati dan meminimalkan tindakan tax avoidance agar sesuai dengan peraturan pajak yang berlaku dan tetap mempertahankan reputasi perusahaan.

\section{Pengujian Hipotesis 3:}

Apakahprofitabilitas

berpengaruh terhadap tax avoidance dengan kepemilikan institusional sebagai variabel moderasi ? signifikan sebesar $0,002<0,05$. Hasil ini menunjukkan bahwa profitablitias berpengaruh terhadap tax avoidancesecara positif karena perusahaan memerlukan nilai yang baik di mata publik maka profitabilitasnya harus tetap baik. Pada saat perusahaan mengalami profitabilitas yang meningkat maka peluang untuk meminimalkan pajak yang dibayarkan semakin besar melalui tindakan tax avoidance. Keterlibatan kepemilikan institusional dalam hal ini berkaitan dengan jumlah deviden yang akan diberikan dari profitabilitas yang didapatkan oleh perusahaan. Semakin besar tindakan tax avoidance maka akan memungkinkan semakin besar jumlah deviden yang akan diberikan kepada pemegang saham institusional.

\section{Simpulan}

Setelah melakukan pengujian maka penelitian yang dilakukan penulis menghasilkan kesimpulan bahwa variabel karakter eksekutif tidak berpengaruh terhadap tax avoidance secara parsial. Sedangkan variabel 
ukuran perusahaan dan profitabilitas berpengaruh secara parsial terhadap tax avoidance. Secara simultan karakter eksekutif, ukuran perusahaan dan profitabilitas berpengaruh terhadap tax avoidance. Kepemilkan institusional sebagai variabel pemoderasi terbukti memperkuat hubungan antara variabel dependen dan variabel indpenden dalam penelitian ini.

Saran yang dapat peneliti berikan mengingat keterbatasan yang dialami peneliti bagi penelitian selanjutnya adalahmenambah variabel good corporate governance, menggunakan proksi yang lain dalam mengukur tax avoidance misalnya book tax gap.

\section{Daftar Pustaka}

Annisa, Nuralifmida Ayu dan Lulus Kurniasih (2012), Pengaruh Corporate Governance Terhadap Tax Avoidance, Jurnal Akuntansi \& Auditing, Mei Vol. 8, Universitas Sebelas Maret, Surakarta.

Ayu, Dyah dan Rini Hastuti (2009), Persepsi WP: Dampak pertentangan Diametral Pada Tax Evasion WP Dalam Aspek Kemungkinan Terdeksinya
Kecurangan, Keadilan, ketetapan, Pengalokasian, Teknologi Sistem Perpajakan, dan Kecenderungan Personal (Studi WP Orang Pribadi).Kajian Akuntansi.

Budi Judiman, 2012, Pengaruh Karakter Eksekutif Terhadap Penghindaran Pajak (Tax Avoidance), Universitas Gadjah Mada, Semarang, diakses 8 Oktober2014.

Chen, Shuping et al (2008), Are Family Firms More or Less Tax Aggressive?, Journal of Financial EconomicsVol. 95, pp. 41-61.

Cooper, Donald R. dan Schindler, Pamela S. (2006), Metode Riset Bisnis, Volume 2, Edisi 9, Jakarta: PT. Media Global Edukasi.

Dyreng at al. 2008, Long-Run Corporate Tax Avoidance, The Accounting Review, Vol. 83, No. 1, pp 61-82, diakses 9 Oktober 2014.

Dyreng at al. 2010, The Effects of Executive on Corporate Tax Avoidance, The Accounting Review, Vol. 85, No. 4, pp. 1163-1189, diakses 9 Oktober 2014. Ghozali Imam (2006), Aplikasi Analisis Multivariate dengan Program SPSS, Semarang: Badan Penerbit Universitas Diponegoro. 
Hanafi, Umi \& Harto P. 2014, Analisis Pengaruh Kompensasi Eksekutif, Kepemilikan Saham Eksekutif dan Referensi Risiko Eksekutif Terhadap Penghindaran

Pajak

Perusahaan, Diponegoro Journal of Accounting,Volume 3, Nomor 2, Tahun 2014, Halaman 1-11, diakses 20 Desember2014.

Hanlon, Michelle dan Shane Heitzman (2010), A Review of Tax Research, Journal of Accounting and Economics50,pp. 127-178.

Harryo S., Hendri (2009), Skripsi: Analisis Rasio Likuiditas, Rasio Leverage, Dan Rasio Profibilitas Serta Pengaruhnya Terhadap Harga Saham Pada Perusahaan-perusahaan Sektor Pertambangan Yang Listing di BEI, Fakultas Bisnis dan Manajemen, Universitas Widyatama.

http://www.ortax.org

Jensen, Michael C. dan William H. Meckling (1976), Theory of The Firm: Managerial Behavior, Agency Costs and Ownership Structure, Journal of Financial Economics Vol. 3, No. 4, pp. 305-360.

Kementrian Keuangan Republik Indonesia, Data Pokok APBN 2006-2012, diakses 13 Oktober 2014.
Mardiasmo (2009), Perpajakan Edisi Revisi 2009, Yogyakarta: Penerbit ANDI.

Mohammad Zain, AK. (2005), Manajemen Perpajakan, Jakarta: Salemba Empat.

Nawawi, Hadari dan Hadari, Martini M. (1995), Kepemimpinan yang Efektif, Yogyakarta : Gadjah Mada University Press.

Nugroho, Elfianto (2011), Skripsi: analisis Pengaruh Likuiditas, Pertumbuhan Penjualan, Perputaran Modal Kerja, Ukuran Perusahaan Dan Leverage Terhadap Profibilitas Perusahaan (Studi Pada Perusahaan Manufaktur Yang Terdaftar pada BEI pada Tahun 2005-2009, Fakultas Ekonomi,Universitas Diponegoro.

Paligorova, Teodora 2010, 'Corporate Risk Taking and Ownership Structure', Working paper/Document de travail, 2010-3, diakses 23 Oktober 2014

Republik Indonesia. 2007. UndangUndang No. 28 Tahun 2007 Tentang Ketentuan Umum dan Tata Cara Perpajakan. Lembaran Negara RI Tahun 2007, No. 85.Sekretariat Negara. Jakarta.

Reza, Faizal (2012), Skripsi: Pengaruh Dewan Komisaris dan Komite Audit Terhadap 
Penghindaran

Pajak,

Universitas Indonesia.

Rusydi, M. Khoiru dan Dwi Martani

(2014), Pengaruh Struktur

Kepemilikan

TerhadapAggressive Tax

Avoidance, Simposium Nasional

Akuntansi XVII, 24-27

September, Mataram.

Sartori, Nicola (2008), Effect of

Strategic Tax Behaviors on

Corporate Governance, Social

Science

Research

Network, diakses 17 Desember

2014,www.ssrn.com

Suandy, Erly (2008), Perencanaan

Pajak, Edisi 4, Jakarta: Salemba Empat

Suminarsi, Wahyu dan Supriyadi 2011, Pengaruh Keadilan,

Sistem Perpajakan, Dan Diskriminasi Terhadap Persepsi WP Mengenai Etika

Penggelapan Pajak (Tax Evasion), Universitas Gajah Mada, Yogyakarta, diakses8 Oktober 2014.

Suryani, Alfiah (2010), Skripsi:

Pengaruh Rasio Leverage, Rasio Likuiditas, dan Firm SizeTerhadap Kinerja Perusahaan Yang Masuk Dalam Kelompok Jakarta Islamic Index Periode 2004-2008, Fakultas Syariah, UniversitasIslam Negeri Sunan Kalijaga.
Sugiyono (2009), Metode Penelitian Bisnis, Bandung: AFLABETa, CV.

Scott, William R. (2003), Financial Accounting Theory, Edisi 3, Toronto: Prentice Hall.

Waluyo, (2013), Perpajakan Indonesia Edisi 11 - Buku 1. Jakarta: Salemba Empat.

Watts, Ross L. dan Jerold L. Zimmerman (1983), Agency Problems, Auditing, and the Theory of the Firm: Some Evidence, Journal of Law and Economics,Vol. 26, No. 3, pp. 613-633.

Zemzem, Ahmed dan Khaoula Ftouhi (2013), The Effects of Board of Directors, Characteristics on Tax Aggressiveness, Journal of Finance and 